Article

\title{
Explorations in Authority in the Daodejing: A Daoist Engagement with Hannah Arendt
}

\section{Thomas Michael}

School of Philosophy, Beijing Normal University, 19 Xinjiekou Outer St, BeiTaiPingZhuang, Haidian Qu, Beijing 100875, China; maike966@gmail.com; Tel.: +86-182-0115-3679

Received: 22 October 2018; Accepted: 19 November 2018; Published: 22 November 2018

\begin{abstract}
The present study is an attempt to liberate the thought of the Daodejing from the constraints imposed on it by both traditional Confucian exegesis and modern Western sinological methodologies in the effort to engage the thought of the work more directly. Because the language and thought of the Daodejing are somehow oddly foreign to the Western traditions of analytic philosophy and sinology, this study attempts to make the Daodejing more familiar by recourse to the tradition of continental philosophy, in this case by taking recourse to Hannah Arendt and in particular to her seminal essay on authority. Engaging Arendt's understanding of authority, this study offers a new look at the thought of the Daodejing by discussing issues that lie at the heart of its political vision, including natural versus political authority, power and coercion, and the relation between authority, tradition, and religion. This study also attempts to situate the fate of the Daodejing's conception of authority in Chinese political history, and it concludes with a brief look at the contemporary comparative philosophical project that brings the Daodejing into conversation with continental philosophy.
\end{abstract}

Keywords: Laozi Daodejing; Hannah Arendt; authority

\section{Situating Authority in Arendt and the Daodejing}

The origins of the Daodejing are hidden in mystery, about which only a few things can be reckoned with a high degree of probability. One is that it circulated orally before its teachings were transcribed into the complete eighty-one chapter transmitted edition by which it is read today. Another is that those who originally owned these oral teachings were not those who subsequently transcribed them. ${ }^{1}$ It is also possible that the original teachings emerged from techniques of bodily cultivation believed to lead to a condition described as sagehood, and that those who took possession of the teachings after their transcription into the Daodejing were first of all concerned with political philosophy. The important consequence of this is that the sage of the originally oral teachings, likely best understood as a master of the early techniques of $q i$ 氣 (breath) circulation, was transformed into an enlightened king who rules over a unified empire.

To take this political reading as normative does violence to what may be the original bodily cultivation core of the teachings, not least of all because it does not adequately get to the heart of the Daodejing's actual political vision in which the sage plays no prominent role. On one side, its core political vision involves issues of justice and resistance to the spread of tyrannical rule in the world, and on the other it concerns the foundational grounds of legitimate authority, a subject that has received scant attention in the scholarly literature. One reason for this is that the Daodejing's concern

1 I am persuaded that the original oral teachings were in circulation by the fourth century $\mathrm{BCE}$, and although there are three early but partial transcriptions excavated from Guodian known as the Laozi writings, the complete eighty-one chapter Daodejing was not transcribed until the end of the third century BCE. For more on this, see Michael (2017). 
with legitimate authority is often seen as neither central nor strong, and when it is a topic of focus, scholars tend to minimize its role into a kind of Heideggerian "letting-be" on the part of the ruler, particularly as the text relies on the metaphor of the mother to discuss it. However, as I hope to show, gaining a more nuanced understanding of the Daodejing's conception of legitimate authority has the potential to open a very different reading of the work's overall vision of the way things are and the way things should be.

In her seminal essay called "What is Authority?", Hannah Arendt analyzes the early Greek attempts, unsuccessful as they were, to found a legitimate authority; the ways in which authority was originally constructed in the founding of the Roman Republic; and the later unfoldings of Western authority up to modernity. The sorts of questions that she asks in her approach to Western authority are entirely apposite for the case of early Daoist conceptions of authority, and these questions concern the nature of legitimate authority, the possibility of a natural authority, the effects of coercion and the role of compliance, as well as the relationship between authority and power. ${ }^{2}$ Arendt displays the historical structures at play in the Western construction of authority, but she also implies that authority itself is a universal; in other words, the historical factors at play in any one culture's construction of authority, where that occurred, are not likely to be repeated in other historical constructions of it, but the authority itself is the same.

The present study attempts to analyze the Daodejing's conceptions of legitimate authority by following the track opened up by Arendt's investigations into Western authority. The legitimate authority articulated by the Daodejing did not take hold in China, primarily because it was overwhelmed by other, predominantly Confucian conceptions of authority. Nonetheless, the Daodejing's conception of it is inextricably bound up with its notions of the pristine Dao, and its grounding of legitimate authority in the natural authority of the Dao had a profound influence on all later Chinese conceptions of political authority.

\section{Arendt on Authority in Greece and Rome}

The English word authority derives from the Latin word auctoritas, which itself derives from the Latin word augere (augment), and this presents two immediate connotations that are here only mentioned: authority as expansion and as addition. Authority is not an inherent feature of existence or experience; it is always subsequent to a previously established and functional life-world. ${ }^{3}$ Once founded, however, authority gradually pervades as a perpetually intrusive atmosphere to be ignored only at great risk to one's well-being.

Authority concentrates in political bodies, and in the development of states it cements as state sovereignty. Although they are often and erroneously conflated, the present study does not directly engage with notions of power, but its differences with authority should be noted. In Michel Foucault's (1978, p. 92) understanding, authority is centered and invested in "a group of institutions and mechanisms that ensure the subservience of the citizens of a given state." It requires networks of power relations, surveillance, and punishments by which its agents coordinate their enforcement of authority's directives at each of its terminal points and must therefore be centered in "a unique source of sovereignty," a ruling body that emanates its own legitimacy. About power, Foucault (1978, pp. 92-93) writes:

2 Another fruitful way to comparatively approach the Daodejing's conception of authority lies through the thought of Gramsci (1978), particularly with respect to his understanding of hegemony, since his views are as much to the point as Arendt's. However, given the complexities of his thought, it is unreasonable in a study such as this to incorporate them, and that remains the matter of a future study.

3 I employ the term "life-world" (German Lebenswelt) throughout this study in its normative phenomenological meaning as referring to the shared horizon of intersubjective experience, the lived ground in which all phenomena appear as meaningful and accessible to perception. 
It seems to me that power must be understood in the first instance as the multiplicity of force relations immanent in the sphere in which they operate and which constitute their own organization ... The omnipresence of power: not because it has the privilege of consolidating everything under its invincible unity, but because it is produced from one moment to the next, at every point, or rather in every relation from one point to another. Power is everywhere; not because it embraces everything, but because it comes from everywhere.

Arendt (1961, pp. 92-93) specifies other important differences between power and authority: "Since authority always demands obedience, it is commonly mistaken for some form of power or violence. Yet authority precludes the use of external means of coercion [and] where force is used, authority itself has failed!" As used in this study, authority signifies the general system of domination in which one group exercises the power to direct and command the activities and behaviors of another group(s).

Arendt locates the initial deployment of a specifically political authority in the Roman empire, and she situates it along a continuum with the order of persuasion grounded in argument (the model of the Greek polis) on one side and the authoritarian order of coercion based on violence (likely the model of the ancient Near East) on the other side. Although she cannot locate actualized authority in the Greek polis, she recognizes that, with the breakdown of the Greek political order of persuasion (following the death of Socrates), both Plato and Aristotle attempted to found a legitimate authority that could direct Greek activity. Plato did so, writes Arendt (1961, p. 107), because he came "to discount persuasion as insufficient for the guidance of men and to seek for something liable to compel them without using external means of violence." Because there was no "immediate political experience" of authority at that time, he resorted to other, non-political prototypes, including that of the shepherd and the sheep, the helmsman and the crew, the physician and the patient, and the master and the slave.

In his turn, writes Arendt (1961, p. 115), Aristotle "followed Plato in the main not only by separating a 'theoretical way of life' from a life devoted to human affairs but accepted as a matter of course the hierarchical order implied in it." For his prototype, Aristotle relied on a kind of natural authority that he found in nature and that he believed was also functional in the household, a sphere of life that had been kept sharply separate from politics, and he based it on the difference between "the younger and the older" seen especially in child-rearing and education. As Arendt points out, this effort was doomed to languish because Aristotle's natural authority, much like Plato's prototypes, was entirely different in kind from the authority of political rule and therefore was in no way amenable to translation into governing institutions.

According to Arendt, Rome was the first to establish authority in the strict political sense under issue, where it served as but one leg of a three-part institution next to religion and tradition. Very different from the Greek polis, Rome was established on a sacred foundation ordained by the gods (as powerfully dramatized in the Aeneid) that profoundly informed both its religion and its tradition; Arendt (1961, p. 120) writes:

At the heart of Roman politics, from the beginning of the republic until virtually the end of the imperial era, stands the conviction of the sacredness of foundation, in the sense that once something has been founded it remains binding for all future generations. To be engaged in politics meant first and foremost to preserve the founding of the city of Rome. This is why the Romans ... were capable of adding to the original foundation until the whole of Italy and, eventually, the whole of the Western world were united and ministered by Rome.

With particular attention to authority as augmentation (augere), Arendt (1961, p. 124) writes that it was from this foundation wrought by the ancestors that Rome also forged its past as sanctified through tradition:

Tradition preserved the past by handing down from one generation to the next the testimony of the ancestors, who first had witnessed and created the sacred founding and then augmented it by their authority throughout the centuries. As long as tradition was 
uninterrupted, authority was inviolate; and to act without authority and tradition, without accepted, time-honored standards and models, without the help of the wisdom of the founding fathers, was inconceivable.

I will not pursue Arendt's further analysis of the fate of Western authority post-Rome, but it is important to briefly consider several points raised by her account before turning to the position of authority in the Daodejing. First, authority emerges from an act of political founding; second, the order of authority is separate from the orders of persuasion and coercion; and third, the authoritarian order of coercion, whether as tyranny or despotism, surrounds authority on every side and constantly threatens its dissolution into the violences characteristic of the death-world. ${ }^{4}$

\section{The Authoritarian World of the Daodejing}

In her analysis of the Western construction and deployment of authority, Arendt (1961, p. 104) brings focus to the augmentations intrinsic to it, even as she denies a singular universality to specific historical factors: "Authority as the one, if not the decisive, factor in human communities did not always exist, though it can look back on a long history, and the experiences on which this concept is based are not necessarily present in all bodies politic." Her analysis is solely directed to the processes at play in the construction and transmission of Roman authority, but her findings serve well to frame the possible outlines of other, non-Western authorities, in the present case China. However, while "the experiences on which this concept is based" are uniquely Roman and not likely to be exactly replicated elsewhere, I am persuaded that the phenomenon of authority, where it exists, is globally the same in nature, essence, and function, even as religions and traditions demonstrate tremendous variation in place and time. As Rome's own historical configuration of tradition, religion, and authority presents a solid platform from which to consider the historical configurations at play in other, non-Western constructions of authority, one question to ask is not whether China, particularly at the time of the earliest circulations of the Daodejing, was a place in which authority was exercised, because it was; we might rather inquire into the initial historical configurations that led to its own construction of authority.

Arendt locates the founding of Roman authority simultaneous with the establishment of the Roman Republic, traditionally dated to 509 BCE. For its part, Chinese authority was founded with the establishment of the Zhou Dynasty (1046-256 BCE) some five centuries earlier than Rome. ${ }^{5}$ For the greater parts of China's three thousand years of dynastic succession, authority was a structural component of the sovereign power of its unified empire, singularly invested in the Son of Heaven (天子 tianzi). Even during those periods of political disunity, the ideal of a unified empire under the sanctioned authority of the Son of Heaven was ever assumed in mainstream Chinese political consciousness.

Somewhat similar to the Roman case, the founding of the Zhou evinces its own peculiarly Chinese configuration of religion, tradition, and authority. Arendt (1961, p. 121) writes that authority in Rome was "bound to the specific locality of this one city," whereas Chinese authority was bound to the specific lineage ruling at any one time. Unlike Rome, Chinese authority was mobile within the confines of the geo-political realm marked as "the center" (中 zhong), mythically bounded by the four seas and from which the Son of Heaven received tribute as the mark of his legitimate authority.

The founding of the Zhou Dynasty marks China's entrance into recorded history, understood as the past as described in contemporaneously inscribed bronzes and other forms of historical documents

4 I employ the term "death-world" in distinction to the "life-world" again in its normative phenomenological meaning as established most importantly in Wyschogrod (1983), and which is most succinctly characterized in the transformation of the grieving for "a lost one" into the grieving for "the lost many" that is actively incorporated into the lived experience of those who survive.

5 For more on the Western Zhou, see Shaughnessy (1999). 
available for collection, archive, precedent, and memory. ${ }^{6}$ And although they were likely composed long after the events they purport to describe, the collection of documents collected in the Shujing 書經 7 provide the earliest accounts of the initial construction of Chinese authority, conceived as the sacred Mandate conferred by Heaven (天命 tian ming). ${ }^{8}$ Heaven initially invested its Mandate in King Wen 文王 (1152-1056 BCE), although it was his son King Wu 周武王 (r. 1046-1043 BC) who, following the dictates of Heaven's Mandate, overthrew the reigning Shang Dynasty (ca. 1600-1046 BCE) in armed rebellion. At the coronation of King Wu's son, King Cheng 周成王 (r. 1042-1021 BCE), the gathered ministers proclaimed, "Son of Heaven, imperial Heaven chose to take the Mandate from the imperial state of Shang, giving it to Wen and Wu of the Zhou ... Now, Your Majesty, practice caution by increasing the Royal Army and never again neglect the mandate of your revered high ancestors!" ${ }^{9}$

Such accounts provide the firm outlines of a historically particular configuration of religion, tradition, and authority in the construction of Zhou authority and its expanding sphere of control. Like ancient Rome, the Zhou Dynasty too was founded by human actors effectuating the sacred Mandate of Heaven guaranteed by the influential power of the ancestors who closely monitored its exercise of authority; it was they who showered the dynasty with either fortune or misfortune according to their assessments of the Son of Heaven's obedience to their will. Their standard of assessment was based on the degree to which he maintained the ancestral traditions, chiefly demonstrated in sacrifice to them, illustrated in the Shangshu's depiction of King Cheng's appointment of a minister in the following: "Follow the example of your ancient ones, your virtuous ones, for I can see you are a worthy man like your revered ancestors. Therefore, I appoint you to conduct the correct rituals and protect the relics." 10

The Zhou Dynasty enjoyed a mostly unchallenged exercise of authority for nearly three hundred years until, in $771 \mathrm{BCE}$, the Quanrong 犬戎 tribes sacked its capital and killed King You 周幽王 (795-771 BC). In response, the dynasty could only relocate further east, deeper into the heartland. This bombshell event marked the first stage of the gradual collapse of Zhou authority that would not reach its denouement until 256 BCE with the death of the last Zhou Dynasty Son of Heaven, King Nan 周郝王 (?-256 BCE). In the meantime, the relocation of the capital in 771 BCE marked the end of the Western Zhou (1046-771 BCE) and the beginning of the Spring and Autumn (771-476 BCE). ${ }^{11}$ Throughout this period, Zhou religion and tradition remained substantially intact; however, subsequent rulers witnessed their authority gradually relegated to a merely symbolic role primarily limited to the continuance of the ancestral sacrifices. This has a distant analogue in the Roman case in which, as Arendt (1961, p. 128) writes, "whenever one of the elements of the Roman trinity, religion or authority or tradition, was doubted or eliminated, the remaining two were no longer secure."12

In the course of the Spring and Autumn, the once unified Zhou Dynasty dispersed into a proliferation of hundreds of decentralized kingdoms on a newly minted zongfa 宗法 system ${ }^{13}$ that prescribed rules for clan governance including inheritance, succession, and marriage, in which the eldest sons of the nobility inherited their father's title and rank, while younger sons received a title one rank lower and, together with worthy warriors and statesmen who were not necessarily

6 Of course, the Shang had their oracle bones on which were inscribed records of royally sponsored divinations, but they were not meant to serve as records of history strictu sensu.

See Kern (2017).

8 For more on ming as Mandate and fate, see Lupke (2005).

9 Palmer (2014, p. 165).

10 Palmer (2014, p. 110).

11 For more on the Spring and Autumn, see Hsu (1999).

12 Arendt (1961, p. 128) continues: "Thus, it was Luther's error to think that his challenge of the temporal authority of the Church and his appeal to unguided individual judgment would leave tradition and religion intact. So it was the error of Hobbes and the political theorists of the seventeenth century to hope that authority and religion could be saved without tradition. So, too, was it finally the error of the humanists to think it would be possible to remain within an unbroken tradition of Western civilization without religion and without authority."

13 This system is often erroneously designated as Chinese feudalism; for the problems with this attribution, see Major and Cook (2017, p. 19). 
related by blood, they were also often provided with their own lands, free to establish their own independent kingdoms each with their own legal codes. Next to an unremarkable smattering of small-scale skirmishes, these kingdoms contented themselves with mutual co-existence. Over time and without the protections previously guaranteed by the authority of the Son of Heaven, the proliferating kingdoms proved incapable of containment and the situation devolved into a Hobbesian state of affairs that led to the Warring States (475-221 BCE). ${ }^{14}$

This period witnessed radical military and bureaucratic reforms that ushered in waves of innovative weapon technology coupled with more sophisticated military strategies, as well as ten-fold increases in the size of armies, subjecting the populace to interminable wars. ${ }^{15}$ With legitimate authority in a vacuum and under the rule of newly emergent tyrants, the more powerful kingdoms one by one conquered those incapable of defending themselves and formed into states with a precarious stasis achieved among seven major ones. In the waning years of the Warring States, the situation resolved itself as Qin swallowed each of them in turn, culminating in its establishment of the short-lived Qin Dynasty (221-207 BCE). ${ }^{16}$

Emerging from the ashes of Zhou authority, the political geography of the Warring States was dominated by the authoritarian order of coercion characterized by the arbitrary use of power in the hands of individual tyrants. This was particularly the case with King Zheng 秦政王 (259-210 BCE) of Qin (later the First Emperor of the Qin Dynasty 秦始皇帝), who implemented Legalism as his own ruling ideology. Legalism's most articulate spokesman, Han Feizi 韓非子 (ca. 280-233 BCE), attempted to ground sanctioned authority on his own prototype of "the two handles" (二柄 er bing) of a plow: punishment and reward; Randall Peerenboom (1993, p. 143) writes, "Han Fei confers on the ruler ultimate authority to determine what the laws will be, how they ought to be applied, and whether or not they should be changed ... In the final word, law is what the ruler says it is; it is what pleases the ruler."

I mention Han Feizi not because I am particularly concerned with the fate of post-Zhou authority in China, but because he describes an authoritarian world subject to the order of coercion that long pre-existed him in the Warring States; he simply desired to legitimate it. Other great thinkers of the Warring States also attempted to legitimize authority, of whom Mengzi 孟子 and Xunzi荀子 stand out for their attempts to ground it in a ritual order. Thus, the movement from the Western Zhou to the Qin Dynasty witnessed a fundamental transformation of the life-worlds of early China that brought them under subjection to authoritarian orders of coercion. This is the authoritarian world depicted by the Daodejing, an arena for injustice, brutality, war, and early death.

\section{Ruling Elites, Beleaguered Commoners, and the Sage}

On the surface, the society depicted in the Daodejing is rather simple: it recognizes only three groups: ruling elites, beleaguered commoners, and the Sage. ${ }^{17}$ It is tempting to designate the first two in terms of class, although it is better to avoid that term's modern associations with Weber's stratification in terms of economics, prestige, and power, or Marx's measures in terms of relationship to the means of production and shared class consciousness. The Daodejing does not provide enough sociological detail to make overarching interpretative claims about them, and the present discussion is limited to the specific ways in which they are textually represented.

The ruling elites primarily consist of kings (王 wang) who are sometimes coupled with lords (侯 hou or 公 gong), and they exercise absolute control over the reins of government as well as the wealth of the state. Below them are the common people (民 $\mathrm{min}$ ) who are frequently represented as

\footnotetext{
For more on the Warring States, see Lewis (1999).

5 See Lewis (1990).

For more on the rise and fall of the Qin, see Bodde (1986).

17 One could argue for the inclusion of military men, mentioned about a half dozen times throughout the text, as a fourth category, but as a group they receive no sustained attention and play little role in the philosophical vision surrounding the theme of authority. For more on the Daodejing's attitude toward the tradition of military thought, see Zhang (2015), Michael (2020).
} 
beleaguered commoners powerless to change their pitiable conditions. The ruling elites are far removed from productive labor, while the commoners supply them with their wealth. ${ }^{18}$ These conditions are described in DDJ 53:

Their courts are exquisite but the fields are full of weeds and the granaries are completely empty.

Their clothing is patterned and embroidered and they carry sharp swords on their sides.

They are gorged with drink and food and they have a wealth of possessions and goods.

This is called thievery and aggrandizement and is not of the Dao!

In the world of the Daodejing, the flow of wealth, goods, and resources moves along a single-track originating from the commoners to the ruling elites, and there are no passages that mention any downward flow of actual benefits, material or otherwise, from the elites to the commoners. This is in stark distinction to the Analects, where Confucius in several passages speaks of the various benefits that good rulers provide to the people, as for example in $L Y 16.1$ :

I have heard that what worries the ruler of a state or the chief of a clan is not poverty but inequality, not the lack of population but the lack of peace, for if there is equality there will be no poverty, and if there is peace there will be no lack of population. Under these circumstances, if distant populations still resist your attraction, you must draw them to you by the moral power of civilization and then, having attracted them, make them enjoy your peace.

By contrast, the Daodejing describes only the taking of wealth and resources by the ruling elites for themselves, rendering the commoners struggling for their own survival; DDJ 75 says, "The people are difficult to manage because their superiors pursue their own agendas; for this they are difficult to manage. The people trivialize death because their superiors are consumed with their own pursuit of pleasure; for this they trivialize death." Note the reduplications at the end of each sentence that buttress attention on the plights and travails of the commoners.

Central among the Daodejing's core concerns are equity in the distribution of resources and goods (DDJ 75 says, "The people do not eat their own harvests because their superiors eat the grain tax to excess"); fairness in land allocation and access to the means of production (DDJ 72 says, "Do not reduce their living spaces and do not oppress their livelihood"); and accountability in the meting out of punishment ( $D D J 72$ recognizes that "the common people are in terror of the authority of those in power"). Into this vacuum, the Daodejing posits a single agent of change capable of rectifying the scales of justice: the Sage (聖人 shengren). ${ }^{19}$

The Sage ${ }^{20}$ is best characterized as one who has come to physically embody the Dao. ${ }^{21}$ With respect to the question of authority, four traits differentiate the Sage from the other groups. The first is that he has mastered specific techniques of bodily cultivation involving the circulation of $q i$,

18 This black-and-white social-scape can be compared to the more complex picture presented in the Analects that provides portraits of individually named persons differentiated according to their various ranks, positions, and professions. At the same time, however, the Analects also attempts to erase these social distinctions by its own two-part, black-and-white social division into those who have received education and/or have virtue called 君子 junzi, and those without education and/or virtue called 小人 xiaoren. Both texts have their own strategic reasons for portraying the social world in two starkly opposed binary classes that they hold up for evaluation: the Analects because its overriding concern is with ritual and morality, and the Daodejing because its overriding concern is with tyranny and injustice.

19 I prefer to name this figure in what might be called the archetypal singular as the Sage for several reasons: the Chinese term does not distinguish the singular from the plural; the Daodejing never provides any personal identity to the Sage because $\mathrm{s} /$ he is, like the ruling elites and the beleaguered commoners, never given individual marks of personality; and the Sage directly speaks from time to time in the first person singular, an example of which is found in DDJ 20: "I alone am different from other people: I value drawing sustenance from the Mother."

20 Although the text lays the burden of responsibility for saving the life-world squarely on the shoulders of the Sage, that is the topic of a separate study, but it is worth a brief mention here.

21 An understood sub-category of this third figure, likely the primary audience targeted by the Daodejing, is sages-to-be or those who are amenable to make the existential decision to start on the arduous path of becoming a sage. 
as DDJ 10 implies: "In concentrating the $q i$ and making it soft—can you make it like that of an infant?" The second is that the Sage has an uncanny ability to transform the conditions of others, thereby keeping alive hope for the salvation of the life-world; as DDJ 27 says, "The Sage is constantly good at saving people and rejects nobody, and he is constantly good at saving things and rejects nothing." The third is that the Sage is, from time to time, found amidst the common people but never in the company of the ruling elites, and he feels a profound compassion for their suffering, described in his own voice in DDJ 67: "Because of my compassion, I am able to be courageous ... If one attacks with compassion, then he will win."22

Finally, the Sage is not a king and holds no position in the political order of the state and, fortified with a powerful anti-authoritarian determination, his non-identification with kings places him just this side of anarchy. ${ }^{23}$ Further, unlike the Analects, the Daodejing nowhere harkens back to the now-lost Zhou authority. As DDJ 14 speaks of "the ancient Dao" (古之道 gu zhi dao), and DDJ 15 and 65 both speak of "those in antiquity who excelled at working with the Dao" (古之善為道者 gu zhi shan wei dao zhe), there is no hint that the text is referring to Zhou authority, and it seems to be jumping over relatively recent political history to a more ancient time before the emergence of institutionalized kingship, when people were not yet subject to any centralized regimes.

Long before authoritarian rule infused itself into their life-worlds, the Daodejing holds that the people ( $\mathrm{min}$ ) were always supremely qualified to manage their own forms of social organization and their own agricultural affairs. What it may or may not have considered the legitimate authority of the early Zhou has by now devolved into the brutal authoritarianism of tyrannical rule, and its rapid expansion throughout the Spring and Autumn and into the Warring States has taken hold of all aspects of the life-world, transforming it into a death-world. This is the situation into which the Daodejing attempts to insert its own conception of legitimate authority that it grounds in the pristine Dao.

\section{Aristotle on Natural Authority}

As Max Weber (1978, pp. 212-13) describes it, authority in any of its three forms (traditional, charismatic, and legal) is synonymous with the dominance of one group over another(s). With its absence of legal standards, even traditional authority depends on the ability of the leader to dominate others in the manipulation of traditional standards for the greatest benefit. However, his writings on the routinization of charisma, and authority more generally, do not adequately address the ways in which authoritarian domination can seep into and corrode the legitimacy of any of his three forms of authority, and this raises a fundamental question concerning the legitimacy of legitimacy: what is it that draws or compels people to accept the domination even of non-coercive, legitimate authority in the first place? Foucault $(1978$, p. 92) would argue that the foundations of authority are inseparable from the manifold deployments of power itself: "The analysis, made in terms of power, must not assume that the sovereignty of the state, the form of the law, or the overall unity of a domination are given at the outset; rather, these are only the terminal forms power takes." Still, is it not possible to conceive alternative forms of legitimate authority not based on domination?

Plato and Aristotle both came to the realization that the order of persuasion, central to the structures of the polis, was insufficient to direct human activity. Arendt examined their efforts to establish an alternative political order founded on non-coercive authority and the prototypes that they employed to conceive it. Aristotle attempted to base his model of authority on the order of the household, which he deemed in terms of a natural authority, and Arendt (1961, p. 116) writes: "Aristotle, as far as I can see, was the first to appeal, for the purpose of establishing rule in the handling

22 In this and similar passages, the voice of the Sage serves as a clarion call for resistance to the abuses of power, so it should come as no surprise that the Daodejing had a prominent role in numerous peasant rebellions throughout Chinese history; I return to this in the conclusion.

23 On the question of anarchy in the Daodejing, see Feldt (2010), Stamatov (2014). 
of human affairs, to 'nature,' which established the difference ... between the younger and the older ones, destined the ones to be ruled and the others to rule." 24

According to Arendt (1961, p. 118), the authority that Aristotle deemed "natural" led him "into glaringly contradictory statements, insofar as he superimposes on the actions and life of the polis those standards which, as he explains elsewhere, are valid only for the behavior and life in the household community." Simply stated, Aristotle intended to establish political authority on a household authority that he saw as firmly embedded in nature. This type of authority might be conceived as pre-political, and the reason that it could not translate into the polis is because this "natural" authority was itself still nothing more than an alternative form of domination (of the older over the younger), even as the order of persuasion functional in the polis that it was intended to replace was founded on the equality of a democracy. Taking this natural authority at face value as Aristotle established it, namely as one form of domination among others, then the style of this domination was not that of ruler over ruled; it was, writes Arendt (1961, p. 118), "educational in essence, and in this education no more is involved than the training of the future rulers by the present rulers," where the household was thought of in terms of a "monarchy" more or less synonymous with "tyranny."

The Greek conception of the fullest plenitude of existence is at least partially captured in the notion of agon (struggle or contest), which constantly worked to forge a victor: man against man, man against nature, man against god. ${ }^{25}$ The notion of agon thus appears to inform Aristotle's conception of the dominance that lies at the core of natural authority that, as agon, also functioned to establish dominance, in this case in the patriarch-cum-tyrant standing at the head of the household. Such a notion of struggle continued to dictate conceptions of dominance throughout Western civilization, as for example in the struggle of reason against desire or the soul against the flesh, and it lies even at the periphery of Darwin's more subtle conception of natural selection as the survival of the fittest as applied by Spencer in terms of his "social Darwinism."

The notion of struggle, however, did not play a significant role in Chinese conceptions of either the plenitude of individual existence or the foundational mechanisms of human civilization. The Spencerian platitude that survival belongs to the fittest does not find an appropriate home in the Chinese tradition and could be more fittingly replaced with a platitude more along the line that sees survival as belonging to the most cooperative or the most harmonious, at least as we can imagine it articulated by either Laozi or Confucius.

These divergent ways of conceiving social evolution have something of a pedigree in Western thought and echoes the contrast between Hobbes' view of human nature as competitive and agonistic and Rousseau's view of it as cooperative and collaborative. Certainly there are varying degrees of domination and cooperation at the heart of social evolution in different cultures that are likely influenced by topography, climate, and flora and fauna; nonetheless, it should not raise eyebrows to claim that Plato and Aristotle saw the world through the lens of struggle, while Laozi and Confucius saw it through the lens of cooperation, and their separate perspectives informed the ways in which all four attempted to conceive of legitimate authority.

In the end, Aristotle's natural authority is entirely different in kind from the fundamental sense of authority that Arendt (or even Weber) intends to maintain, namely the considered acceptance on the part of the ruled of the ruler's legitimate power to direct their activities. Therefore, the natural authority that Aristotle believed to be an inherent component of nature and upon which he attempted to ground political authority is simply one further iteration of tyranny, in which absolute power is lodged in the person of the patriarch.

Like Aristotle, the Daodejing also attempts to ground legitimate political authority in natural authority but, unlike Aristotle, its conception is not agonistic.

24 But note here that Arendt appears to be ignoring Plato's invoking of phusci (by nature) in establishing the rank order of ruler and ruled.

25 This non-inclusive language stems from the ancient Greek tradition itself. 


\section{Natural Harmony in the Daodejing}

Although the Warring States period is recognized as the Golden Age of Chinese philosophy, it was nevertheless a historical era of continuous and savage warfare when survival on the level of both the individual and the state could hardly be taken for granted. Likely in reaction to these circumstances, a dominant philosophical concern of the time lay in articulating, justifying, debating, and promulgating the concept of harmony (和 he) as the highest good and the supreme goal in the thought of early China. Two ways to conceive harmony stand out: centripetal and centrifugal. About the former, Roger Ames (1993, p. 62) writes:

"Harmony" is not a given in some prearranged cosmic design, but it is the quality of the combination at any one moment created by effectively correlating and contextualizing the available ingredients, whether they be foodstuffs, farmers, or infantry ... This harmony begins from what is most concrete and immediate and draws from the outside in towards the center.

Ames calls this harmony centripetal because it "draws from the outside in towards the center," regardless if the center is represented as the state, the ruler, the general, or what Hall and Ames (1987, pp. 110-25) call "the authoritative person" (君子 junzi or "gentleman" in common translation). Politically, centripetal harmony informed the ambition of rulers seeking to harmonize China through unification; militarily, it informed the strategies of generals seeking to harmonize the movements of troops in battle; and philosophically, it informed conceptions of harmonized webs of social relationships in which every person finds his or her appropriate position.

The Daodejing advocates a centrifugal harmony. Although this harmony might justifiably be characterized as "a given in some prearranged cosmic design," it is still, to use the terminology of Hall and Ames (1987, p. 247), "emergent" but, unlike centripetal harmony, its emergent nature is only secondarily brought out as "a consequence of human action." This centrifugal harmony is originally and structurally functional in the pristine natural world that also includes human beings, but undergoing the processes of socialization, human beings inevitably displace their natural concinnity with it, thereby synergistically disrupting the harmony of the world itself. It requires a particular kind of "emergent" activity to re-orient a person back into attunement with it, generally referred to as wuwei but specifically characterized as non-intentional action (無為 wuwei), non-eidetic knowledge (無知 wuzhi), and non-objectified desire (無欲 wuyu). ${ }^{26}$

These $w u$-forms of action, knowledge, and desire are outwardly directed to nature, not inwardly directed to the self. Still, to call this harmony centrifugal depends on one's perspective: it is centrifugal because it draws the person out into nature, but from the point of view of the Dao, it is in fact centripetal because, as DDJ 51 and 40 state, “The Dao gives birth to all things" (道生之 dao sheng zhi) and "Reversal is the movement of the Dao" (反者道之動 fan zhe dao zhi dong). For the Analects, centripetal harmony is the achieved result of human activity, but for the Daodejing, centrifugal harmony describes the movements of the natural order of pristine existence into which all beings are born, as depicted in DDJ 42:

Dao gave birth to the One.

The One gave birth to the Two.

The Two gave birth to the Three.

And the Three gave birth to the ten thousand living things.

The ten thousand living things carry yin on their backs and embrace yang.

Through the blending of qi they arrive at a state of harmony.

This abstruse passage opens by depicting the origins of the cosmos from the body of the pre-existing Dao in a sequence of cosmogonic stages. The One refers to the emergent $q i$ 氣 (breath)

26 This characterization is a modification of Hall (2008, pp. 56-60). 
of the Dao, the Two refers to the yang 陽 (expansive) and yin 陰 (contractive) movements of that qi, and the Three refers to the congealing of the pure yang above as Heaven and the pure yin below as Earth, with a middle realm where yin and yang mix and intermingle. With the cosmos now established, the ten thousand living things, including human beings, come to be born within this lineage of the Dao as original mother. At birth, humans “carry yin on their backs and embrace yang” (負陰而抱陽 fu yin er bao yang): this is the image of the new-born emerging from the womb, whose physical body enjoys the perfect harmony of the cosmic energies of life signified by "the blending of $q i^{\prime \prime}$ (沖氣 chong qi). ${ }^{27}$ For the Daodejing, the body of the new-born manifests the perfect harmony into which it is born, a natural harmony.

DDJ 55 further explores this natural harmony:

One who enjoys the fullness of De can be compared to a newborn infant.

Wasps and scorpions, snakes and vipers do not sting him;

Birds of prey and fierce beasts do not seize him;

His bones are supple and his sinews are pliant, yet his grasp is firm;

He does not yet know the union of male and female, yet his penis is aroused:

This is the height of vitality.

He can yell all day, yet he won't become hoarse:

This is the height of harmony.

This passage correlates "the height of harmony" (和之至 he zhi zhi) manifested by the body of the new-born with its "fullness of De" (德之厚 de zhi hou). In mainstream early Chinese thought, the De normally refers to the moral and charismatic virtue that centripetally attracts others, but many of its uses in the Daodejing signify something very different. It holds that that all living things are born into life from the body of the Dao, and they live because of their physical possession of a localized part of it: this is the De, which manifests in the flowing power of their bodily systems of rhythmic circulation. ${ }^{28}$

As a healthy and robust body maintains this flowing power of life in its circulatory systems, it continues to enjoy its harmony with the Dao and the surrounding world of nature and cosmos. The body of the new-born, thus, profoundly embodies the fullness of the De, and its bodily circulation is perfect: it can "yell all day" (終日號 zhong ri hao) and this mirrors the inexhaustible funds of energy of the Dao itself which, as we read in DDJ 4, “is empty but in being used is never used up" (沖而用之 或不盈 chong er yong zhi huo bu ying).

Born into the natural harmony of the Dao, "the height of harmony" of the new-born is maintained so long as it has not yet begun to undergo the processes of socialization. These processes bring on the physical and emotional stresses posed by the sexual, economic, social, and political challenges inevitably encountered in life, installing blockages in the body's rhythmic systems of circulation that are revealed first of all in the weakening of a person's respiratory system and the shortening of breath.

Reared in society with its compulsions to conform distorts the body's inborn harmony. This is due, according to the Daodejing, either to the desires that rely on schemes born of cleverness intended to gratify those desires (with respect to the ruling elite) or to the displacements of that inborn physical harmony required in the struggle to survive (with respect to the beleaguered commoners). In either case, existing in separation from the natural harmony of the cosmos and with deteriorating bodies, neither group of people live out their naturally allotted life spans, and DDJ 55 darkly states: "As soon as beings reach their prime, they begin to age. This is called 'Not of the Dao,' and whatever is not of the Dao dies prematurely."

27 A further meaning of this phrase is "to be a ruler," where the ruler sits on his throne facing south; the ruler has his back to the yin north and faces the yang south. In the context of this passage, it implies that at birth all humans have the capacity to be a sage-ruler, but in the case of most individuals that capacity steadily falls away as the individual grows to maturity. This insight comes from a personal communication with John Major.

28 For a more in-depth study of the De in the Daodejing, see Michael (2015, pp. 157-74). 


\section{The Dao of Heaven}

Arendt speaks of the political orders of persuasion, authority, and coercion, while the Daodejing speaks of only two orders that it calls the Dao of Humans (人道 rendao) and the Dao of Heaven (天道 tiandao). There are resonances that could allow a loose association of Arendt's order of authority with the Dao of Heaven, and the authoritarian order of coercion with the Dao of Humans. DDJ 77 states:

Is not the Dao of Heaven like the drawing of a bow?

It presses down the high and reduces the excessive.

It pushes up the low and adds to the deficient.

The Dao of Heaven reduces the excessive and increases the deficient.

The mechanisms of the Dao of Heaven demonstrate the actual functionality of the Daodejing's natural harmony at work in its maintenance of the natural balance. A good illustration of this can be seen with the bears and the salmon: when the bears are deficient the salmon grow excessive, thus making it much easier for the bears to eat the salmon and thereby increase. This in turn renders the bears excessive and the salmon deficient, at which point the bears grow deficient allowing the salmon to increase, and so the Dao of Heaven continues.

Although DDJ 81 succinctly states that "the Dao of Heaven provides benefit and does not cause injury" (天之道利而不害 tian zhi dao li er bu hai), clearly there is an order of violence at play in the natural world and the bears will continue to eat the salmon. Seen from a wider perspective, however, this violence is but one component of a much more encompassing system of natural harmony in which there is an ecological cooperation between the bears and the salmon that allows each to flourish in their own turn. DDJ 73 images this encompassing system in the metaphor of a net: "Heaven's net is vast, vast, yet nothing slips through" (天網恢恢而不失 tian wang hui hui shu er bu shi), and this "vast net" ecologically, even cosmologically, also includes human beings so long as they maintain their cooperation with the mechanisms of the natural balance of the Dao of Heaven in the same way as the bears and the salmon.

For humans to maintain their cooperative position with the Dao of Heaven is the simplest expression of dignity, compassion, and non-competitiveness. Humans upset this balanced natural order when their desires exceed the limits of satisfaction, driving them to pursue contrived forms of knowledge such as "cleverness" (智 zhi) that are employed to gratify desire, and therefore DDJ 18 says, "When cleverness and intelligence appear, there is great hypocrisy." DDJ 19 advises to "reject" (棄 $q i$ ) cleverness because, as DDJ 65 states, "The reason why people are difficult to regulate is because their cleverness increases." DDJ 65 follows this in a comment about cleverness in the person of the ruler: "Relying on cleverness to rule the state is the calamity of the state." Reaching its upward limit in these ways, the Dao of Heaven gives way to the Dao of Humans, which DDJ 77 articulates in the following: "The Dao of Humans is not the same: it reduces the deficient by supplementing the excessive." 29

Translated into political terms, the inception of the Dao of Humans represents the first urges toward the authoritarian order of coercion, which the Daodejing explains in terms of the systematic transgression of the order of satisfaction. This marks the turn to the upward, one-way redistribution of treasure from the commoners that "reduces the deficient" (損不足 sun bu zu) and into the hands of the ruling elites that "supplements the excessive" (奉有餘 feng you yu).

But the order of satisfaction also works from the top down, in that legitimate authority is sanctioned by the considered acceptance by those whose activities are directed by it. The Daodejing expresses sharp attitudes of resistance and defiance to the actual political rule of its time because it considers that it is illegitimate, in large part because of this one-way redistribution of wealth that

29 The continuance of this passage demonstrates the saving powers of the Sage: "Who is able to reduce the excessive by way of supplementing the world? Only one who possesses the Dao." Since the present study is not focused on the Sage, I will let this thread stand on its own here. 
impedes the people's ability to enjoy even the most minimal levels of satisfaction. In such a situation, they can resist in the hope of reinstituting a certain degree of balance in fairness and equity. If resistance proves ineffective, they may then attempt to revolt, and if that is effective then a new balance can be struck, but if that is not effective then the way to bald tyranny and despotism is laid open; as DDJ 20 puts it, "One who is feared by others must also because of this fear them. Unrestrained, it will never come to an end!"

The transition from the Dao of Heaven to the Dao of Humans is the first step in the transformation of the life-world into the death-world. The effective cause for this is deeply entangled with the dire consequences of systematically exceeding the strict limits of the order of satisfaction that were originally measured according to the natural balance established within the mechanisms of the Dao of Heaven. The Daodejing consistently returns to this concern, and representative passages include DDJ 33: "To know satisfaction is to be rich," DDJ 44: "Knowing satisfaction leads to no danger," DDJ 46: "No disaster is greater than not knowing how to be satisfied ... The satisfaction of one who knows satisfaction provides constant satisfaction."

Is it possible that the inception of the Dao of Humans, the first step on the way to the authoritarian order of tyranny, manifests as a stop-gap reaction to the loss of the natural authority of the Dao in the world in the effort to hold the life-world together by any means possible? Or is the imposition of coercion itself compelled by a transgression of the limits of satisfaction fueled by a perverse urge to accumulate and hyper-consume? Is the displacement of the Dao of Heaven in the transition to the Dao of Humans the result of an intrusive benevolence or a licentiousness selfishness? In the face of the ravages caused by the intrusion of illegitimate forms of authority into the life-world, the question is of only academic interest because, in such a situation, the Daodejing attempts to push back against the rank injustice of devastating taxation, the senseless loss of life in the ceaseless interstate wars, and the radical disruption to the people's productive ability to direct themselves even as the ruling elites wantonly annex their lands.

The growing separation of human existence from the natural harmony of the Dao and the overturning of the natural balance of the Dao of Heaven manifests the space upon which the authoritarian order of coercion is originally founded. The ultimate consequence of this is to displace the presence of the Dao in the world, the precise situation described in DDJ 46: "When the world has the Dao, plow-horses are used in the fields. When the world is without the Dao, war-horses are reared on the borders of the state." These two different conditions applied to the same horses illustrate the fundamental transformation of the natural harmony of the life-world into the perverse ravages of the death-world.

\section{Authority as Augmentation}

Authority (auctoritas) is always subsequent to the existence of the life-worlds that it gathers under its umbrella, and it is an augmentation (augere) in two senses: as addition and expansion. ${ }^{30}$ As expansion, it seeks to extend the benefits of its guaranteed protections (legal, economic, military, etc.) to those within its realm against those who would threaten them from without, and an ever-expanding authority is the surest way to secure those protections. As addition, authority signifies the power of the ruler to direct the activities of the social and productive forms of life without recourse to coercion, but it does not itself create them: they are always already capable of satisfying the basic requirements of their own survival. Authority is thus a subsequent augmentation that establishes itself within and

30 There is a third connotation of augere as augury that also deserves a seat at this table, which would imply that there is a kind of channel from the ruler to the divine that allows for glimpses into the future normally concealed from ordinary mortals. If this be so, then it is not unreasonable to consider that the claims about authority made by the Daodejing imply a connection with something higher, which, I believe, is one of the points of the Daodejing. Although I owe this insight to the anonymous reviewer, a fuller treatment of it remains the matter of a separate study. 
on top of the already existing life-worlds that it directs, and its basic function is to coordinate them in their interactions with each other.

Authority is by nature hierarchical and depends on a clear division of labor between those who perform productive activity and those who direct it, but it is not an inherent component of human existence. In his ruminations on authority, according to Arendt (1961, p. 115), Plato distinguished "a 'theoretical way of life' from a life devoted to human affairs," where the former is the only viable path leading to the "good life" (eudaimonia). However, the "theoretical way of life" is and can only be subsequent to "a life devoted to human affairs," because it is only the latter that satisfies the basic needs of survival: food, clothing, housing, etc. Arendt (1961, p. 117) writes: "As living beings, concerned with the preservation of life, men are confronted with and driven by necessity. Necessity must be mastered before the political 'good life' can begin, and it can be mastered only through domination. Hence, the freedom of the 'good life' rests on the domination of necessity."

Certainly, there is a strictly logical separation between the mastery of necessity (the result of an already existing life-world), and its domination. DDJ 80 evokes an idyllic picture of harmonious rural life "in small states with few people" where "they relish their food and take pleasure in their clothing, they delight in their customs and feel content in their homes." These small states, devoid of domination or competition much less the tyranny of an authoritarian state, have already mastered necessity through their systems of cooperation that, even before the infiltration of state domination, have fulfilled the preconditions for competition and domination, namely the previous organization of resources and manpower and the previous production of goods that, we can reasonably imagine, are distributed fairly and equitably.

These small states of the Daodejing share with the polis a localized nature without the political domination exercised by rulers having either legitimate or illegitimate authority. Weber would claim that these "small states" together with the polis are still under the domination of traditional household authority, but that type of household authority, as discovered by Aristotle, cannot translate into the legitimate political authority of the state. At the same time, sinologists also typically understand these small states of the Daodejing as existing prior to the establishment of political authority, and they tend to see in them an order of primitivism, as first described by A. C. Graham (2001, p. 198):

For the Primitivist, the meaning of Daoism is essentially social and political, the defense of human spontaneity against a state which suppresses by punishments and beguiles by moral appeals ... The Primitivist is an extremist who despises the whole of moral and aesthetic culture. He wants to revert to the simplest mode of life, undisturbed by the temptations of luxury and sophistication, intellectual abstraction, above all by Confucian and Mohist moralism.

Although Graham is discussing a set of chapters from the Zhuangzi and he does not here specifically identify the Daodejing as Primitivist, the label has stuck to it, as attested by Harold Roth (1999, p. 7): "Following A. C. Graham, (the Daodejing) can be called 'Primitivist' because of its advocacy of this vision of a simple society and politic." Bryan Van Norden (1999, p. 203) takes this to the next level:

We must not forget the aspects of primitive society that the Daodejing does not emphasize. Most of the children in this "utopia" will die from diseases before they reach maturity. The adults will toil in the fields from dawn until dusk, with little time for leisure. In bad years there will be mass starvation. And unless one accepts the details of the Daodejing's cosmology, there is no reason to believe there will be no assault, theft, murder, and even the occasional witch hunt in this primitive society.

Even without necessarily accepting "the details of the Daodejing's cosmology," these sinological views are narrow-minded and do not take account of the fact that the Daodejing in fact endorses something approaching a unified empire in which the small states are brought into more expansive 
systems of cooperation with each other (see next section), as well as the fact that societies existing before the implementation of the orders of either legitimate authority or illegitimate authority (tyranny or despotism) are not to be systematically deemed primitive, as evidenced by the polis with its democratic order of persuasion.

Thus, it is not too far-fetched to consider that these small states of the Daodejing existed in self-sufficient cooperation among themselves and were organized according to something like the democratic order of persuasion found in the polis. The goods produced through such originally local systems of cooperation provide the conditions for the initial formations of authoritative systems of domination, and it is precisely in this sense that the imposition of authority is an addition laid on top of already functional and productive life-worlds. On this point, Arendt (1961, p. 118) writes:

The free man, the citizen of the polis, is neither coerced by the physical necessities of life nor subject to the man-made domination of others ... The freedom of the political realm begins after all elementary necessities of sheer living have been mastered by rule, so that domination and subjection, command and obedience, ruling and being ruled, are preconditions for establishing the political realm precisely because they are not its content.

Arendt pursues her discussion of authority as something that is other than yet added onto the "sheer life" of necessity by recalling Plato's notion of the philosopher-king who dominates by way of his theoretical way of life over against the life-world of the non-philosopher, and she (Arendt 1961, p. 115) writes that "the interest of the philosopher and the interest of man qua man coincide; both demand that human affairs, the result of speech and action, must not acquire a dignity of their own but be subjected to the domination of something outside their realm," which is precisely the position, role, and function of political authority.

We can say that, in terms of authority, Plato and Aristotle sought the proper grounds upon which to legitimate and establish political authority over and above the necessity of sheer existence, and while the Daodejing would not necessarily dispute this notion of authority as addition, it decisively underplays the role of domination. When the Daodejing rails against the imposition of illegitimate political power, it makes a distinct separation on one hand between legitimate authority exercised by means other than domination (or at least it never explicitly associates authority and domination) and, on the other hand, illegitimate power and the authoritarian order of coercion.

\section{Authority in the Daodejing}

In the world of the Daodejing, human society has already failed to abide by the cooperation systems of "the vast net" of the Dao of Heaven; as DDJ 18 states, "the great Dao is rejected" (大道廢 da dao fei). On what grounds could the Dao have originally established those cooperation systems in the first place? It could have done so only on the grounds of its own natural authority. To better approach this question of the Dao's natural authority, it is necessary to look back to a time before the transformation of the life-world into the death-world, because it is only there that this natural authority can be seen in its full magnitude as it directs the actions of all living things. And while this natural authority of the Dao is not directly translatable into actual political authority, political authority is and can only be legitimized, at least according to the Daodejing, by means of it. In this sense, the ruler's legitimate political authority to direct behavior is itself an augmentation of the Dao's natural authority in its connotation of addition.

Aristotle sought to found his natural authority on the prototype of the patriarch, and the Daodejing seeks to found its natural authority on the prototype of the mother. However, the difference between them is not a simple inversion of gendered household roles because these two prototypes function on different grids: as the patriarch is not in every way identical with the father, so the mother too is not identical with the matriarch. The patriarch is head of the household because of a physical power that excludes women and offspring from it, and this grid is set within a kinship model, whereas the mother gives birth to and succors new life, and this grid is set within a biological model. While there 
are arguments to make, rightly or wrongly, that both models represent a form of natural authority, there is little to no ground shared between them. ${ }^{31}$

A better analogue to the Daodejing's image of the Dao as the mother would be the Old Testament's image of God as the father, ${ }^{32}$ given that Aristotle's patriarch shares many traits with him. God and the Dao have a plenitude of authority, and in both cases their authority is natural and not received from outside of themselves. The ultimate basis of their natural authority is that they brought the world into existence, but God did so from an act of creation in seven days, whereas the Dao did so from a process of birthing over a protracted period of time. Further, each depends on their natural authority to direct the actions of all beings, but God does so through direct spoken commands, whereas the Dao does so through unspoken mechanisms. Both also exercise authority over different kinds of moral codes, but God's moral code is based on obedience to his commands (the Ten Commandments), whereas the moral code of the $\mathrm{Dao}^{33}$ is based on compliance with the natural balance (the Dao of Heaven). Finally, both have a final authority over the life and death of all beings that far transcends the purview of human authority.

The Dao exists as a pregnant mother before the beginning of the first formations of the cosmos; DDJ 52 states, “The world had a beginning that can be taken as the mother of the world" (天下有始以 為天下母). Among the many passages that repeatedly state that the Dao gives birth to all that exists, DDJ 21, 25, and 42 taken together provide a complete depiction of the cosmogonic birthing processes on the biological grid of gestation and parturition. ${ }^{34}$ That the Dao gives birth to all that exists is both a measure and a demonstration of the natural authority of the Dao because it is the ultimate foundation upon which the legitimacy of its natural authority rests.

The Dao's natural authority, much like actual political authority, is expressed in its directives for behavior as well as in the compliance to its directives on the part of all living things subject to its authority. These directives are set forth in the terms and dictates of the Dao of Heaven (analyzed in the previous section) and concern the structures of, and the balance between, life and death; thus, DDJ 81 states, "The Dao of Heaven is to benefit and not injure." The Dao has sanction to establish its directives because of its natural authority, which is most clearly spelled out in $D D J 51$, parts of which are repeated in DDJ 10, and in DDJ 34. Note that DDJ 51 discusses the De together with the Dao: the Dao gives birth to and exercises authority over all living things, and the De, as a physical localization of the Dao, functions as a kind of secondary reinforcement of that natural authority.

31 This comparison between the different conceptions of natural authority in Aristotle and the Daodejing might lead us to the conclusion that the latter's construction of authority as maternal is polemical, both anti-ancestral and anti-generational. Recognizing the failure of Aristotle's patriarchal family > state model, this historically contextualized point of view would show that Confucius grounds his understanding of authority on a quite similar model, one for which the Daodejing would deny any continuity, generation to generation, of the ritual and material foundations of clan organization. In $L Y 2.23$, Confucius is asked if it is possible to know the future ten generations hence, to which he replies, "The Yin adapted the rituals of the Xia, and we can know what was discarded and what was added. The Zhou adapted the rituals of the Yin, and we can know what was discarded and what was added. If a different dynasty succeeds the Zhou, we can know what it will be like, even after a hundred generations." I wish to thank the anonymous reviewer for this insight, even as it adds another deep layer of investigation to be pursued in a future study.

32 It is important to note that while God played an important role in the Western history of political authority, he did not found it but assumed his role late, long after authority had already been established in the founding of Rome. This too is discussed by Arendt (1961, pp. 125-36).

33 I use this expression with hesitation only to draw a parallel with the Western case, because if there is such a thing as "the moral code of the Dao" (and I believe that there is), it is somewhat confounding.

34 For a more in-depth analysis of these cosmogonic processes, see Michael (2005, pp. 15-32; 2011, pp. 101-26). 
The Dao gives birth to them, ${ }^{35}$ events form them.

venerate the Dao

veneration of the Dao

The Dao gives birth to them.

They are given birth but not possessed.

They are acted for but not put into service.

They are grown but not put under command.
The De nurtures them; circumstances complete them.

For this reason, none among the ten thousand living things does not

and honor the De.

As for this

and honoring of the De:

Nobody orders it, it is constantly spontaneous.

This is why:

The De raises them.

It grows them and rears them.

It fosters them and nurses them.

It nurtures them and shelters them.

This is called Profound De.

\section{DDJ 34 states:}

The great Dao pervades everything, it goes left and right.

The ten thousand things depend on it for their birth, but it does not give orders.

This merit accomplished, it does not go on to possess them.

Clothing and nourishing the ten thousand things, it does not act as their master.

Taken together, DDJ 51, 10, and 34 provide a thorough account of the Dao's natural authority. This is a natural authority that does "not possess" (不有 bu you) living things, it does "not put them into its service" (不恃 bu shi), and it does “not put them under its command" (不宰 bu zai). It neither possesses them nor acts as their master, yet all things rely on it for their life: I suggest that if this is not a natural authority, then it would not be an issue whether the Dao commanded living things or not. But precisely because this is the issue, the text therefore says that the Dao does not abuse its authority in such ways.

When the text states that living things "venerate the Dao" (尊道 zun dao), this sounds counter-intuitive, for how could a lion or an oak venerate the Dao? They simply submit to its natural authority by their spontaneous compliance with the Dao of Heaven, and they venerate the Dao by being what they are-the oak venerates the Dao as it blooms in spring and as its foliage changes color before falling in autumn, while the lion venerates the Dao in its majestic chase of the gazelle, even as the gazelle venerates the Dao by fleeing the clutches of the lion hot on its tail. For the oak not to bloom

35 I present this chapter in its Interlocking Parallel Style (IPS) in which the separate remarks about the Dao and the De are placed in their own individual columns. For more on the IPS structure, see Wagner (1980), and for a translation of the Daodejing that applies it, see Michael (2015). 
in the spring, for the lion not to hunt the gazelle, and for the gazelle not to flee for its life would signify their rejection of the Dao of Heaven and their refusal to venerate the Dao. In contrast, as humans systematically transgress the order of satisfaction, they demonstrate their refusal to venerate the Dao, their rejection of the Dao of Heaven, and their denial of the natural authority of the cosmic Dao.

A further feature of the Dao's natural authority is that it is not spoken, as implied in DDJ 51 and directly stated in $D D J 73$ : "The Dao of Heaven does not strive yet it is good at overcoming; it does speak yet it is good at being followed; it does not summon yet others spontaneously come." The text itself spells out the enforcement mechanisms that undergird the authority of the Dao's directives and the sanctions or consequences for rejecting it: not death as such but rather an early death that $D D J$ 30 and 55 directly announce: "Whatever is not of the Dao dies prematurely" (不道早已 bu dao zao yi). Perhaps DDJ 42 states this most bluntly: "What others teach, I also teach: "Those who are violent and brutal will not have a natural death.' I take this as the father of my teachings." Despite this mechanism of capital retribution built into the very fabric of life, the natural authority of the Dao is not founded on the order of coercion, since one part of legitimate authority is surely the right to exercise sanctioned violence. DDJ 79 caps this: "The Dao of Heaven has no favorites: it constantly sides with good people."

However, natural authority in any iteration, whether from Aristotle or the Daodejing, is insufficient to direct the activities of social communities enmeshed in political bodies; only legitimate political authority can accomplish that, which raises a further question about the Daodejing's conception of legitimate political authority. Some scholars claim that it advocates keeping society in a pre-political, primitive state, ${ }^{36}$ other scholars claim that its political ideal is one of numerous decentralized states, ${ }^{37}$ while yet other scholars claim that it endorses a unified empire under centralized kingship. ${ }^{38}$ To mitigate the uncertainty involved with this issue requires clarifying the differences between a unified versus an inclusive empire.

Political authority for the Daodejing is legitimate if and only if it is grounded in the natural authority of the Dao and exercised without coercion in accordance with the Dao of Heaven. As such, it eschews centripetal unification in the sense of assimilated uniformity because that would impede the ability of the many states to individually nurture their own life-worlds. What the Daodejing endorses is a centrifugal inclusiveness of the many states under centralized kingship where, according to DDJ 80, "People will relish their food and take pleasure in their clothing, they will delight in their customs and feel content in their homes." Thus, when DDJ 61 speaks of "small states" (小國 xiao guo) being taken over by "the large state" (大國 $d a$ guo), the small states are virtually encouraged to maintain their own life-worlds: "The large state desires nothing more than to bring others together and rear them, and the small states desire nothing other than to offer its services to others." 39

The centralized kingship of this inclusive empire is legitimized by its grounding in the natural authority of the Dao, identified in DDJ 59 as "the mother of the state" (國之母 guo zhi mu) that, like rivers and oceans, naturally takes the lowest position, as DDJ 66 states: "The reason why rivers and oceans are able to be the kings of the hundred rivulets is that they are good at taking the lowest position." DDJ 61 continues this image of the large state as female: "The large state is like the lowest reaches of a river, the convergence point of the world: it is the female of the world." This is inclusion, not unification.

Political authority is legitimate for the Daodejing only if it is grounded in the natural authority of the cosmic Dao and exercised by a legitimate ruler in compliance with the directives of the Dao of

36 This is the position of Graham, Roth, and Van Norden mentioned in the previous section.

37 Hall (2008, p. 56) provides a philosophical basis for this view where he writes, "Thus the testimony of the Daodejing is that the world is to be seen as a plurality: a many, not a one. Such an understanding of the world precludes the notion of cosmos, insofar as that notion entails either a coherent, single-ordered world or a congeries of entities with essential features or essential modes of connection."

38 No one single study stands out because most English-language approaches to the Daodejing read it as a kind of manual of kingship, and Schwartz (1985, pp. 186-254) can be taken as standard and straight-forward.

39 Note that this passage also provides a pure illustration of the systems of cooperation discussed in the previous section. 
Heaven in an inclusive empire. I strongly resist blanket identifications of the Daodejing's sage with the ruler as conceived by other, non-Daoist early Chinese writings, and one important reason for this is not just that the text makes a strong distinction between the sage and the king, but also because it makes a strong distinction between both of them on one hand, and the Son of Heaven (tianzi) on the other. The Son of Heaven appears one time in the text, in DDJ 62, in a sublime portrait of his sanctioned enthronement that is well-worth quoting because it portrays the sacred transference of the Dao's natural authority to the political authority of the ruler:

When the Son of Heaven is being enthroned and the Three Ministers installed, though one offers disks of jade preceded by the four horses, it would not compare to offering this Dao while remaining in one's seat.

Here the Daodejing offsets "the disks of jade" (璧 bi), the timeless insignia of royal authority, to the offering of the Dao itself, and they cannot compare. Although at first glance it seems odd that the Daodejing would recognize the legitimate ruler of the inclusive empire as the Son of Heaven, there is absolutely no question here that his legitimate authority is sanctioned by Heaven's Mandate-it is sanctioned exclusively by the cosmic Dao which, in the eyes of the Daodejing, is itself (herself?) the ancestor of Heaven; as DDJ 4 says, the Dao "seems to have preceded Di" (象帝之先 xiang di zhi xian)..$^{40}$ At the same time, there is also no question here that the sage, as one who embodies the Dao, is identified with the Son of Heaven, for who is it that "offers this Dao while remaining in his seat" (坐進 此道 zuo jin ci dao)? Only the sage.

The Daodejing nevertheless sharply curtails the sanctioned powers of the ruler, whose primary directive as caretaker of the inclusive empire is to allow the independent life-worlds of the many small states to flourish without interference from threats either internal or external. Next to this, the further authority that the Daodejing concedes to him involves representing the natural authority of the Dao in his dedication to protecting and safeguarding the various dictates of the Dao of Heaven, including non-aggression, non-violence, and non-injury, as DDJ 39 implies: "If lords and kings were without these standards by which they are ennobled and made high, they will topple." DDJ 78 expresses this on a virtually self-sacrificial level: "Only he who takes upon himself the disgraces of the state is called lord of the altars of earth and grain. Only he who takes upon himself the misfortunes of the state is called king of the empire."

Other than his willingness to sacrifice himself, the Daodejing recognizes few other individually identifying characteristics of the legitimate ruler, because his sole value derives only from the authority of the position. The authority of the position, on the other hand, is ennobled with a profoundly cosmic value that is effectuated by way of the Dao's natural authority as the source of all life, and the downward flow of its natural authority finds its terminal point in the political authority of the position of the king, as DDJ 25 states: "The Dao is great. Heaven is great. Earth is great. And the king is also great. In the center of the realm these are Four Greats, and the king occupies one place among them."

The "greatness" (大 $\mathrm{da}$ ) of the king is subordinated to the "greatness" of Earth, then to the "greatness" of Heaven, and finally to the "greatness" of the Dao. Thus, from the perspective of the ruler, the flow of authority is centrifugal, but the natural authority of the Dao is itself the center and source of the king's political authority, and therefore, from the cosmic perspective of the Dao, this authority is centripetal. DDJ 35 compellingly refers to this cosmic natural authority of the Dao as the "Great Image" (大象 daxiang): "Hold to the Great Image and the whole world will follow. When it follows and suffers no harm, it enjoys security and peace."

40 The term Di 帝 refers to an ancient semi-anthropomorphic deity who first appears in the Shang Dynasty oracle bones to whom sacrifices were directed, primarily by rulers. There is an intimate connection between the Shang god Di and the moral force of Heaven (tian) popularized by the Zhou, but the gist of this passage from DDJ 4 is that the authority of the Dao supersedes both. For more on the similarities and differences between Di and Heaven, see Chang (2000). 
Received in an act of transference from the cosmic Dao, the legitimacy of the ruler is continuously sanctioned only as he submits his political authority to the natural authority of the Dao while both safeguarding the dictates of the Dao of Heaven as well as personally complying with them. In this, DDJ 59 is without a doubt the Daodejing's most important and comprehensive chapter concerning the activities and responsibilities of the legitimate ruler, primarily because it squarely situates his rule in direct relation to the Dao of Heaven:

In regulating the people and serving Heaven, nothing compares with being frugal. Being frugal is to submit early to the Dao.

Submitting early is to accumulate the De repeatedly.

Accumulating the De repeatedly, there is nothing that cannot be overcome.

When there is nothing that cannot be overcome, nobody knows where it will end.

When nobody knows where it will end, then the state can be possessed.

And when the mother of the state is possessed, one is long and lasting.

This called the Dao of deep roots and a solid base.

It is the Dao of long life and lasting vision.

Here, the legitimate ruler's primary responsibility is "to serve Heaven" (事天 shi tian), a task that he discharges by safeguarding the dictates of the Dao of Heaven (previously announced in DDJ 82 as “to benefit and not injure"). He "serves Heaven" by "early submitting [to the Dao]" (早服 [道] zao fu [dao]), a submission performed by "being frugal" (嗇 se). For the legitimate ruler to be "frugal" is for him to personally comply with the Dao of Heaven, which for him primarily means that he does not transgress the limits of the order of satisfaction, as stated in DDJ 13: "The world can be entrusted to one who values his body as much as the world. The world can be turned over to one who loves his body as much as the world." This is to say that when thirsty he drinks, when tired he sleeps, when hungry he eats, and that is all. ${ }^{41}$

By not transgressing the order of satisfaction, he "accumulates the De repeatedly" (重積德 chong ji de), where the De retains its particularly Daoist meaning as the physical force of the powerfully rhythmic flow of his bodily systems of circulation that vitally connect his body to the cosmic Dao. Maintaining his compliance with the dictates of the Dao of Heaven, then "the mother of the state is possessed" (有國之母 you guo zhi mu), and he is thereby no longer subject to a corporal "early death" (早已 zao yi) because, as previously announced in DDJ 42, “Those who are violent and brutal will not have a natural death." Consequently, he is (shall we say with the sanctioned allowance of the Dao?) "long and lasting" (長久 chang jiu) since he exercises his legitimate authority in attunement with "the Dao of long life and lasting vision" (長生久視之道 chang sheng jiu shi zhi dao).

About this Dao, DDJ 32 says: "In its simplicity it is small, yet the world does not dare to put it into its service." As the ruler submits his political legitimacy to the natural authority of the Dao even as he rules in compliance with the Dao of Heaven, a cosmic fusion involving the "Four Greats" of DDJ 25 together with not just humanity but all living things is effectuated, as envisioned in DDJ 32: "Were lords and kings able to preserve the Dao, then the ten thousand living things would spontaneously submit, and Heaven and Earth would come together to release sweet dew. It would naturally fall equally on all things, without a single person ordering it." DDJ 37 re-presents this vision in slightly modified form: "Were lords and kings able to preserve the Dao, the ten thousand living things would spontaneously transform."

The ruler "preserves" (守 shou) the Dao by submitting his political authority to its natural authority, the result of which is to transform the world into a profound harmony symbolized by the "release of sweet dew" (降甘露 jiang gan lu) that falls equally on all living beings. As the ruler submits to the Dao,

41 This particular insight comes from a private conversation with Robin Wang, who is not necessarily innocent of various other claims made in this study. 
so then do all living beings also submit, but their submission is not to the ruler; rather, this too is a submission to the natural authority of the Dao as demonstrated by their compliance with the dictates of the Dao of Heaven.

$D D J 71$ provides a powerful image of the fused relationship of political with natural authority in what it calls the "Great Authority" (大威 $d a$ wei): "When the common people are not in terror of the authority of those in power, then will arrive the Great Authority."

\section{The Authority of the Dao in History}

Early Chinese conceptions of the Dao have an ancient pedigree, but two thinkers indissolubly stamped them each with their own separate perspectives: for Confucius, the Dao is the measure of the progress of human culture, whereas for Laozi the Dao is the mother of the cosmos. ${ }^{42}$ After the loss of Western Zhou hegemony followed by the collapse of the Spring and Autumn feudal order, Chinese thinkers of the Warring States took the notion of the Dao as arguably the most important concern; Graham (1989, p. 3) writes of them that:

Their whole thinking is a response to the breakdown of the moral and political order which had claimed the authority of Heaven; and the crucial question for all of them is not the Western philosopher's. 'What is the Truth?' but 'Where is the Way [Dao]?', the way to order the state and conduct personal life.

The Daodejing grounded its conception of legitimate authority squarely on the pristine Dao, a powerful view that was in direct contradiction to other, more mainstream Chinese conceptions (but importantly Confucian) of imperial authority that were firmly grounded in the legitimacy of Heaven and sanctioned by the reception of its Mandate. These two conceptions of legitimate authority were often in open conflict for many centuries after the appearance of the Daodejing.

The latter years of the Warring States saw the establishment of a new tradition that modern scholars even today do not fully understand called Huang-Lao Daoism 老道. ${ }^{43}$ This label derives from combining the name of the putative author of the Daodejing, Laozi 老子, with the name of an important god who enjoyed great popularity throughout Chinese history, Huangdi 帝. In all likelihood, this tradition originally formed in large part by way of a political reading of the Daodejing initially articulated in the works of Han Feizi ${ }^{44}$ that saw its sage as an enlightened ruler whose authority was legitimated not by Heaven but by the Dao according to the terms set forth by the Daodejing.

The success of Huang-Lao in carrying the Daodejing's conception of authority to the climactic heights of imperial recognition neatly coincides with the lifetimes of its two most important imperial adherents: Empress Dowager Dou 寶猗房 (ca.205-135 BCE) and the Prince of Huainan, Liu An 劉安 (164-122 BCE) ${ }^{45}$ both of whom strongly endorsed Huang-Lao notions of authority that were deeply informed by the Daodejing. In a series of events that ultimately led to the execution of Liu An, Huang-Lao was brusquely ejected from the imperial courts immediately following the enthronement of Han Emperor Wu 漢武帝 (r. 141-87 BCE), convinced as he was by the arguments of Dong Zhongshu 董仲舒 (179-104 BCE), a scholar who ardently advocated for an imperial ideology that, if not strictly identifiable with Confucianism, would soon become one of its foundations. ${ }^{46}$ Anna Seidel and Lothar von Falkenhausen (Seidel and von Falkenhausen 2008, p. 148) write:

During the reign of Emperor Wu, Huang-Lao Daoism thus disappeared from politics and, by the same token, vanished almost completely from the historical sources of the age. It is

\footnotetext{
42 For a more in-depth comparison of these two understandings of the Dao, see Michael (2017, pp. 67-92).

43 See Seidel (1992); Cao (2017).

44 See Kim (2010).

45 See Vankeerberghen (2001).

46 For a considered study of Dong's thought, see Wang (2005); for a concise discussion of the events concerning Dong and Emperor Wu, see Queen and Major (2016, pp. 1-36).
} 
not until almost three centuries later that the official histories mention Daoism again-at a point when it had once again attracted the attention of the upper classes, as manifested in the form of Daoist cults at court and religiously motivated popular insurrections.

These insurrections percolated around a congeries of peasant rebellions involving secret Daoist societies associated with the likes of the Yellow Turbans (黃巾 huangjin), the Celestial Masters (天師 tianshi), and others that erupted in $185 \mathrm{CE}$ and were not finally put down until $205 \mathrm{CE}$. But by that point the damage was done, and the unified Han Dynasty broke into three separate kingdoms. ${ }^{47}$ The adherents of these societies worshipped the deity called Laojun 老君, none other than the deified form of Laozi, and they took the Daodejing, a text harshly critical of the abuses of political power, as their central scripture and primary inspiration. Seidel and von Falkenhausen (2008, p. 127) write:

This deification of Laozi was not the fruit of theological speculations of a religious elite, nor was it the result of pious legend-mongering with a system of popular religion; it was, rather, the expression of how a mystical expression of statecraft previously current under the upper strata was transformed into a popular mass-movement of politico-religious, even messianic characteristics.

It comes as no surprise that these rebellions were undertaken with the explicit intent to do away with the authority of Heaven's Mandate and replace it with a Daoist Mandate sanctioned by Laojun himself. ${ }^{48}$

It was during this period of the last decades of the Han that two of the earliest commentaries to the Daodejing appeared. One is the Xiang'er 想 ${ }^{49}$ that served as a catechism for the early Celestial Master movement, and it draws a sharp distinction between the sage and the king while investing leadership of its community in the sage. The other was called the Heshang Gong 河上公, 50 and it closely follows the Huang-Lao interpretation of the Daodejing by directly identifying the sage with the enlightened king ruling over a unified empire legitimated by the natural authority of the Dao. Neither commentary makes an appeal to the Mandate of Heaven, instead locating the source of legitimate political authority in the Dao.

After the fall of the Han and into the period of the Three Kingdoms, there continued to be a succession of further messianic Daoist movements spearheaded by the Sun En 孫恩 rebellion. ${ }^{51}$ This period also saw the establishment of a Daoist theocratic state, namely the Northern Wei, that lasted about twenty-five years and whose legitimacy was sanctioned by the Dao and not by Heaven. ${ }^{52}$ China would not again be unified until the establishment of the short-lived Sui Dynasty (581-618) followed by the more enduring Tang Dynasty (618-907) — both of which, as circumstances have it, were also founded on a specifically Daoist authority. ${ }^{53}$

With the fall of the Tang, Daoist authority no longer played any role of note in Chinese imperial history, and Song Dynasty Confucians, once again fully armed with their Mandate of Heaven, ferociously reestablished themselves in Chinese government and society, a position that they maintained throughout the final thousand-year succession of late imperial dynasties (the Yuan, Ming, and Qing). After the fall of the Qing, China passed four turbulent decades without any stable forms of political authority until Mao Zedong founded the People's Republic of China in 1949, whose legitimacy was grounded in a Western form of authority powerfully articulated Marx and Lenin, but with Chinese characteristics.

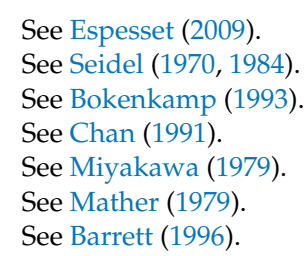




\section{The Daodejing and the Project of Comparative Philosophy}

As a text, the Daodejing circulated in an oral form before becoming transcribed in the final years of the Warring States. Once it did, the first writing to discuss it in any detail was the Hanfeizi, ${ }^{54}$ and it assumed that the figure of the sage was synonymous with some conception of a sage-king. Because this reading was taken up by both the tradition of Huang-Lao and Confucianism, from that point on and for the most part, identifying the sage of the Daodejing with a ruler took hold in the Chinese philosophical tradition, where it remains a dominant feature even in most contemporary Western readings of the work.

However, the Daodejing itself clearly differentiates the sage from kings as well as from the Son of Heaven (DDJ 62), the single figure who actually represents the enlightened ruler in the text. To misread the distinctions between these three figures and take them together as all referring to the same person does serious damage to the ideas of the text, particularly as this impinges on its understanding of the role of legitimate authority invested in the legitimate ruler (the Son of Heaven) that is grounded in the natural authority of the cosmic Dao.

A recent example of the problems inherent in identifying the sage with the ruler is found in Hans-Georg Moeller's (2006) study of the politics of the Daodejing. In it, the sage is systematically identified with the sage-ruler, and Moeller also does not recognize the position of the Son of Heaven next to the sage on one hand and the rulers (all of whom are very bad characters) on the other. In addition to Moeller's (2006, p. 65) odd assertion that the sage-ruler that he finds in the Daodejing is the recipient of Heaven's Mandate to govern the empire, he (Moeller 2006, p. 60) also writes that "the ruler has no duties, no specific service to fulfill," because this describes the "non-activity" (無為 wuwei) of his position. However, Moeller's (2006, pp. 69-70) brief discussion of DDJ 78 goes on to state that this sage-ruler is "the master of the ceremonies that unite human society and their agricultural production with heaven and earth," and I can only take this as being in contradiction to the sage-ruler's expressed non-activity. To serve as the master of such ceremonies is in fact an essential duty of the Son of Heaven, and it is anything but doing nothing.

Next to this, the Son of Heaven 天子, who is neither a sage 聖人 nor a ruler 王, has other very serious duties and services as described in previous sections of this study. These include his obligation to submit his legitimate authority to the natural authority of the cosmic Dao, and also to uphold and safeguard the dictates of the Dao of Heaven.

If my reading of authority in the Daodejing is not entirely mistaken, then it is very much obligated to a view on authority that has been deeply clarified by Arendt. Moeller is not alone in reading the sage of the Daodejing as a sage-king, and he is also not alone in not directly engaging with issues of authority (natural, political, or otherwise); the nearest he gets to this, which is much closer than the majority of other scholars who speak about the political views of the Daodejing, comes where he (Moeller 2006, p. 58) writes that "the sage-ruler is the source of efficacy-but does not act." But I think for the Daodejing it is in fact the natural authority of the cosmic Dao that is the source of the Son of Heaven's political authority, and he also acts. It is only the sage who truly "does nothing" (wuwei), or as I translate the Chinese phrase, the sage "acts non-intentionally" —and in doing so, s/he transforms the world. The Son of Heaven and the sage have entirely different roles in the Daodejing.

I believe that opening up the study of the Daodejing to an approach grounded in a more philosophically comparative perspective will assist in our ability to better understand this fascinatingly enigmatic work, which has for far too long been held captive by traditional Confucian exegesis and the strict limitations it has imposed on our ability to hear the text. To date, the most outstanding proponents of exposing the Daodejing to such a philosophically comparative project have tended to rely on the philosophies of Nietzsche, Heidegger, and Derrida. ${ }^{55}$ The present study's attempt to bring

54 See Kim (2010).

55 Outstanding among are Parkes (1987, 2013), Froese (2006), and Burik (2009). 
Arendt's substantively political thought into this project could not be possible without their pioneering efforts, and it is my hope that the present study can contribute to this project in some small way.

Funding: This research received no external funding.

Conflicts of Interest: The author declares no conflict of interest.

\section{References}

Ames, Roger. 1993. Sun-Tzu the Art of Warfare: The First English Translation Incorporating the Recently Discovered Yin-ch'üeh-shan Texts. New York: Ballantine.

Arendt, Hannah. 1961. What Is Authority? In Between Past and Future: Six Exercises in Political Thought. New York: Viking Press.

Barrett, Timothy H. 1996. Taoism under the T'ang: Religion and Empire during the Golden Age of Chinese History. London: Wellsweep Press.

Bodde, Derk. 1986. The State and Empire of Ch'in. In The Cambridge History of China, Volume 1: The Ch'in and Han Empires $221 B C-A D$ 220. Edited by Dennis Twitchett and Michael Loewe. Cambridge: Cambridge University Press, pp. 20-102.

Bokenkamp, Stephen. 1993. Early Daoist Scriptures. Berkeley: University of California Press.

Burik, Steven. 2009. The End of Philosophy and the Task of Comparative Thinking: Heidegger, Derrida, and Daoism. New York: State University of New York Press.

Cao, Feng. 2017. Daoism in Early China: Huang-Lao Thought in Light of Excavated Texts. New York: State University of New York Press.

Chan, Alan. 1991. Two Visions of the Way: A Study of the Wang Bi and the Ho-Shang-Kung Commentaries on the Laozi. New York: State University of New York Press.

Chang, Ruth. 2000. Understanding Di and Tian: Deity and Heaven from Shang to Tang Dynasties. Sino-Platonic Papers. No. 108. Edited by Victor Mair. Philadelphia: Dept. of Asian and Middle Eastern Studies, University of Pennsylvania, Available online: http:/ /www.sino-platonic.org/complete/spp108_chinese_deity_heaven. pdf (accessed on 22 November 2018).

Espesset, Grégoire. 2009. Latter Han Religious Mass Movements and the Early Daoist Church. In Early Chinese Religion, Part One: Shang through Han (1250 BC-220 AD). Edited by John Lagerwey and Marc Kalinowski. Leiden: Brill, pp. 1061-102.

Feldt, Alex. 2010. Governing Through the Dao: A Non-Anarchistic Interpretation of the Laozi. Dao 9: 323-37. [CrossRef]

Foucault, Michel. 1978. History of Sexuality Volume 1: An Introduction. Translated by Robert Hurley. New York: Pantheon Books.

Froese, Katrin. 2006. Nietzsche, Heidegger, and Daoist Thought: Crossing Paths In-between. New York: State University of New York Press.

Graham, A. C. 1989. Disputers of the Tao: Philosophical Argument in Ancient China. Chicago: Open Court Press.

Graham, A. C. 2001. Chuang-Tzu: The Inner Chapters. Cambridge: Hackett Publishing.

Gramsci, Antonio. 1978. Selections from the Prison Notebooks. London: Lawrence and Wishart.

Hall, David. 2008. The Daode Jing and Comparative Philosophy. In Teaching the Daode Jing. Edited by Gary DeAngelis and Warren Frisina. Oxford: Oxford University Press, pp. 49-60.

Hall, David, and Roger Ames. 1987. Thinking through Confucius. New York: State University of New York Press.

Hsu, Cho-yun. 1999. The Spring and Autumn Period. In The Cambridge History of Ancient China: From the Origins of Civilization to 221 BC. Edited by Michael Loewe and Edward Shaughnessy. Cambridge: Cambridge University Press, pp. 545-86.

Kern, Martin, ed. 2017. Origins of Chinese Political Philosophy: Studies in the Composition and Thought of the Shangshu (Classic of Documents). Leiden: Brill.

Kim, Tae Hyun. 2010. Other Laozi Parallels in the Hanfeizi: An Alternative Approach to the Textual History of the Laozi and Early Chinese Thought. Sino-Platonic Papers, No. 199. Edited by Victor Mair. Available online: http:/ / sino-platonic.org/complete/spp199_laozi_hanfeizi.pdf (accessed on 22 November 2018).

Lewis, Mark Edward. 1990. Sanctioned Violence in Early China. New York: State University of New York Press. 
Lewis, Mark Edward. 1999. Warring States: Political History. In The Cambridge History of Ancient China: From the Origins of Civilization to 221 BC. Edited by Michael Loewe and Edward Shaughnessy. Cambridge: Cambridge University Press, pp. 587-650.

Lupke, Christopher, ed. 2005. The Magnitude of Ming. Honolulu: University of Hawai'i Press.

Major, John, and Constance Cook. 2017. Ancient China: A History. New York: Routledge.

Mather, Richard. 1979. K'ou Ch'ien-chi and the Taoist Theocracy at the Northern Wei Court, 425-451. In Facets of Taoism: Essays in Chinese Religion. Edited by Holmes Welch and Anna Seidel. New Haven: Yale University Press, pp. 103-22.

Michael, Thomas. 2005. The Pristine Dao: Metaphysics in Early Daoist Discourse. New York: State University of New York Press.

Michael, Thomas. 2011. The That-Beyond-Which of the Pristine Dao: Cosmogony in the Liezi. In Riding the Wind: New Essays on the Daoist Classic, The Liezi. Edited by Ronnie Littlejohn and Jeffrey Dippmann. New York: State University of New York Press, pp. 101-26.

Michael, Thomas. 2015. In the Shadows of the Dao: Laozi, the Sage, and the Daodejing. New York: State University of New York Press.

Michael, Thomas. 2017. Approaching Laozi: Comparing a Syncretic Reading to a Synthetic One. Frontiers of Philosophy in China 12: 10-25.

Michael, Thomas. 2020. Strategic Sages and Cosmic Generals: A Daoist Perspective on the Intertextuality of the Daodejing and the Sunzi. Dao: A Journal of Comparative Philosophy, in press.

Miyakawa, Hisayuki. 1979. Local Cults around Mt. Lu at the Time of the Sun En's Rebellion. In Facets of Taoism: Essays in Chinese Religion. Edited by Holmes Welch and Anna Seidel. New Haven: Yale University Press, pp. 83-102.

Moeller, Hans-Georg. 2006. The Philosophy of the Daodejing. New York: Columbia University Press.

Palmer, Martin. 2014. Confucius: The Most Venerable Book (Shang Shu). New York: Penguin.

Parkes, Graham. 1987. Thoughts on the Way: Being and Time through Lao-Zhuang. In Heidegger and Asian Thought. Edited by Graham Parkes. Honolulu: University of Hawai'i Press, pp. 105-44.

Parkes, Graham. 2013. Lao-Zhuang and Heidegger on Nature and Technology. Journal of Chinese Philosophy 39: 122-33.

Peerenboom, Randall P. 1993. Law and Morality in Ancient China: The Silk Manuscripts of Huang-Lao. New York: State University of New York Press.

Queen, Sarah, and John Major. 2016. Luxuriant Gems of the Spring and Autumn Attributed to Dong Zhongshu. New York: Columbia University Press.

Roth, Harold. 1999. Original Tao: Inward Training (Nei-yeh) and the Foundations of Taoist Mysticism. New York: Columbia University Press.

Schwartz, Benjamin. 1985. The World of Thought in Ancient China. Cambridge: The Belknap Press of Harvard University Press.

Seidel, Anna. 1970. The Image of the Perfect Ruler in Early Taoist Messianism: Lao-tzu and Li Hung. History of Religion 9: 216-47. [CrossRef]

Seidel, Anna. 1984. Taoist Messianism. Numen 31: 161-74. [CrossRef]

Seidel, Anna. 1992. La Divinisation de Lao Tseu dans le Taoisme des Han. Paris: École Française d'Extrême-Orient.

Seidel, Anna, and Lothar von Falkenhausen. 2008. The Emperor and His Councillor: Laozi and Han Dynasty Taoism. Cahiers d'Extrême-Asie 17: 125-65. [CrossRef]

Shaughnessy, Edward. 1999. Western Zhou History. In The Cambridge History of Ancient China: From the Origins of Civilization to 221 BC. Edited by Michael Loewe and Edward Shaughnessy. Cambridge: Cambridge University Press, pp. 292-351.

Stamatov, Aleksandar. 2014. The Laozi and Anarchism. Asian Philosophy 24: 260-78. [CrossRef]

Van Norden, Bryan. 1999. Method in the Madness of the Laozi. In Religious and Philosophical Aspects of the Laozi. Edited by Mark Csikszentmihalyi and Philip J. Ivanhoe. New York: State University of New York Press, pp. 187-257.

Vankeerberghen, Griet. 2001. The Huainanzi and Liu An's Claim to Moral Authority. New York: State University of New York Press.

Wagner, Rudolf. 1980. Interlocking Parallel Style: Laozi and Wang Bi. Études Asiatiques 34: 18-58. 
Wang, Robin. 2005. Dong Zhongshu's Transformation of Yin-Yang Theory and Contesting of Gender Identity. Philosophy East and West 55: 209-31. [CrossRef]

Weber, Max. 1978. Economy and Society: An Outline of Interpretative Sociology. Berkeley: University of California Press. Wyschogrod, Edith. 1983. Spirit in Ashes: Hegel, Heidegger, and Man-Made Mass Death. New Haven: Yale University Press. Zhang, Ellen. 2015. 'Weapons are Nothing but Ominous Instruments': The Daodejing's View on War and Peace. In Chinese Just War Ethics: Origin, Development, and Dissent. Edited by Ping-cheung Lo and Sumner B. Twiss. New York: Routledge, pp. 181-208.

(c) (C) 2018 by the author. Licensee MDPI, Basel, Switzerland. This article is an open access article distributed under the terms and conditions of the Creative Commons Attribution (CC BY) license (http://creativecommons.org/licenses/by/4.0/). 